\title{
Determinants of Agricultural Output in Doba Woreda, Oromia National Regional State, Ethiopia
}

\author{
Getaye Gizaw \\ Oda Bultum University
}

\begin{abstract}
This Research was conducted to examine the determinant of agricultural output in Doba woreda. The objective of the study was to identify the major determinants of agricultural output in the study area. In order to achieve this objective, the study used both primary and secondary source of data. The primary data was collected through questionnaires and interviews. The secondary data was collected from agricultural office of the woreda and from other documents. The sampling technique was random sampling method with sample size of 100 respondents. The collected data was analyzed and interpreted using descriptive statistics. The majority farmers of the woreda live with large family size, small and fragmented land, large number of illiteracies, use traditional method of farming, and low female participation in the agricultural activities which lead agricultural productivity low. To avoid such problems, the woreda administration should be provide subsidy, credit with low interest rate, give training to illiterate to the farmers and also appreciate to use irrigation to avoid rainfall uncertainty.
\end{abstract}

Keywords: Agriculture, determinant and output

DOI: $10.7176 / \mathrm{JESD} / 12-9-05$

Publication date:May $31^{\text {st }} 2021$

\section{Introduction}

Agriculture is the world most important sector. It provides with all our food, raw material for most of agro based industries and create important opportunity to large population of developing countries. As one of developing countries in the world Ethiopian agriculture sector accounts for about 43 percent of national gross demotic product (GDP),90persent of export and 86perent of employment (ADB, 2016). The role of agriculture in economic development has been viewed as a passive and supportive. Based on historical experience of western countries, economic development was seen as requiring a rapid structural transformation of the economy from one predominantly focused on agricultural activities to a more complex modern industrial and service society. As a result, agriculture's primary role was to provide sufficient low-price food and man power to the expanding industrial economy which was thought to be the dynamic leader sector in any overall strategy of economic development (Todaro, 2016)

Agriculture has been the dominant sector of the Ethiopian since its independence. It is still contributing about 41.4 percent to GDP and employing 70 percent of the total employment. It also provides raw material to industry and contributes to the country's exports. Agriculture sector is also a large market for the industrial products such as fertilizer, pesticide, tractors and agricultural equipment. Major crops of the agriculture are wheat, sorghum, cotton, sugarcane, and rice. Agriculture sector of Ethiopian may be divided into four subsectors comprising major crops, fisheries, forestry and livestock. Comprising major crops is the most important subsector of the agriculture. According to the Ethiopian Economic Survey 2014-15, li comprising major crops contributes 41.8 percent in the GDP of Ethiopian. Crops and livestock constitute the large part (Ethiopian Economic Survey 2014-2015)

Despite its importance, the performance of agricultural sector in Ethiopia has been unsatisfactory compared to the rapid population growth, for instance, the average growth rate of agriculture during the year 19741991(Dergue)was $2 \%$ which is lower than of population growth $3 \%$. Similarly the average growth rate of agricultural sector was $2.27 \%$ between 1982-1996 in agricultural sector leads the country to have considerable food insecurity. As a result, increasing agricultural output is the key factor to reduce poverty (Befkado, 2015). In Ethiopia improvement in agricultural sector require a more efficient use of rural resource such as land; labor and capital since the resources are major input of production.

\section{Statement of the problem}

In sub-Saharan African countries like Ethiopia, where the small-scale farming dominates, the overall national economy agricultural production and productivity is very poor. The agriculture of the economy is characterized by limited use of improved input and back ward agricultural activity. The sector has been declining at the rate of $1.2 \%$ per annual, (CSA, 2015). For the last 42year in Ethiopia majority of people live in rural areas, we need no further evidence than the over worsening poverty situation of the rural population realizing on poor agricultural productivity. Even worse as size of countries population increase per capital income gained from the agricultural sector has been declining consequently the level of income is low and failed to meet the food demand of the over growing population (CSA, 2015). 
Parminder and Amarjeet (2015) attempted to investigate growth rates of TFP and technical efficiency in agriculture sector for the Indian economy using time series data between 1971 to 2014. The variables used in the study were value of output, value of machines, value of labor and value of fertilizer used in the sector. They used data envelopment analysis to compute the results. They found that growth in productivity is negative for Indian economy and output growth of the economy was mere due to growth in inputs in agriculture sector. They also concluded that the change in efficiency was insignificant.

The majority of Doba woreda population resides in the rural areas and are engaged in some forms of agricultural production .particularly, the development of agricultural output in Doba woredas is influenced by; traditional method of farming with little change in farming practice in this woreda, depletion of soil fertility, lack of modern input, environmental and infrastructural constrains lack or insufficiency of expertise in promoting agricultural policy and land use planning, agricultural causes and surveys. this study will identify the determinant of agricultural out-put in Doba woreda. Since no study was undertaken previously regarding the determinant of agricultural output in Doba woreda. Even though there were many studies which are similar to these studies which were undertaken as a whole of Oromia region as well as other woredas of the region no study has been conducted in Doba woreda so far. So, the contribution of this study is identified more about; the determinant of the agricultural output of the farmer in the study area.

\section{Research methodology}

The study Was carried out in Doba woreda. Doba is one of the woredas found in West Hararghe in Oromia region of Ethiopia. It is part of the Lixaa (West)Hararghe zone. Doba is bordered on the south by Chiro, on the north by the Goro Gutu the west by Miesso and on the east by Tullo woreda. Based on the 2008 national census conducted by the central statically agency of Ethiopia, this woreda has a total population of 271,018 of whom 138,282 are men and 132,736 were women;50,032 or $8.46 \%$ of its population were urban dwellers. The major economic activities of this woreda is both crop and livestock production. The crop produce in the woreda are, sorghum, maize, chat and other cereals and the major livestock are cattle, Camels, donkeys, goat and sheep and etc.

To achieve the objective of the study, the researcher was used both primary and secondary data. Primary data was collected from randomly selected respondents through distributing questionnaires and interviewing. The questionnaire had been including both close ended and open-ended questions so as to correct suggestions of respondents. The secondary data was collected from different source such as book, internet and other published documents related to the topic like agriculture and rural development office of the woreda. To acquire the necessary data on the determinant of agricultural output in Doba woreda, simple random sampling method had been used. By using a simple random sampling, the researcher was selected three kebeles out of 44 kebeles. Due to all kebeles in the woreda have similar agricultural activities the researcher had been selected only 3 kebeles as sample which namely walqixumaalbsa, lencowadesa and Tokkuummaa.

The total number of farmers in the 3 kebeles that was participated in agricultural activity was 5000 form this total number of farmer 100 respondents was taken as a sample size of each kebeles. the 3 kebeles were walqixumaaIbsa $=1800$; Lencowadesa $=1750$; Tokkuummaa $=1450$. The researcher selects 30 from walqixumaaIbsa, 40 from Lencowadesa and 30 from Tokkuummaa. The selection technique was proportional to their populations. After data was collected the information and getting back the adequate number of responses, the collected data was structured and tabulating with relative categories to made it manageable, reliable and understandable then the data had been analyzed and interpreted by using both qualitative and quantitative approach. The result of the analysis presented by using tables and percentages.

\section{Data analysis and interpretation}

4.1. General characteristics of the respondents

Table 1: Sex Distribution of sample respondents

\begin{tabular}{|l|l|l|}
\hline Sex & Number of Respondents & Percentages \\
\hline Male & 76 & $0.76 \%$ \\
\hline Female & 24 & $0.24 \%$ \\
\hline Total & 100 & $1 \%$ \\
\hline
\end{tabular}

Source: own survey, 2020

From the above table, $76 \%$ of the sample respondents were males and the remaining $24 \%$ of the sample respondents were females. This implied that female participation in agriculture production is very low. In the study men and women have a separate role to play a greater contribution is agriculture production. There is backward attitude behind the culture of the society in the study area. This make women to work long hours in home and decrease the time they spend in agricultural production. From this point of view, what the researcher is observing is that the majority of the society in the study area have back ward attitude for women regarding to agriculture. Therefore, because of these and other problems the agricultural output is very low since, gender 
discrimination in the study area in terms of agricultural activity by the societies.

Table 2: Age distribution of respondents

\begin{tabular}{|l|l|l|}
\hline Age & Respondents & Percentages \\
\hline $15-30$ & 4 & $0.04 \%$ \\
\hline $31-45$ & 34 & $0.34 \%$ \\
\hline $46-65$ & 56 & $0.56 \%$ \\
\hline Above 65 & 6 & $0.06 \%$ \\
\hline Total & 100 & $1 \%$ \\
\hline
\end{tabular}

Source; own survey, 2020

The above table shows $0.56 \%$ of the respondent's age range from $46-65$ years, $0.34 \%$ of respondent's age ranges from $31-45$ years and $0.04 \%$ and $0.06 \%$ of the respondents age is between $15-30$ and above 65 years old, respectively. This implies that the majority of the respondents' age is between 46-65 years old. The age groups are mostly unproductive. Because of this, agricultural productivity of the respondents is very low. This means that between the age of 46-65 and above 65 years old people are not more participated day to day in their agricultural activities. Therefore, the agricultural out become very low.

Table 3: Distribution of the sample respondents with respect to education level

\begin{tabular}{|l|l|l|}
\hline Educational Level & Number of respondents & Percentages \\
\hline Illiterate & 54 & $0.54 \%$ \\
\hline Writing and reading & 20 & $0.20 \%$ \\
\hline $1-4$ & 14 & $0.14 \%$ \\
\hline $5-8$ & 10 & $0.10 \%$ \\
\hline $9-10$ & 2 & $0.02 \%$ \\
\hline Total & 100 & $1 \%$ \\
\hline
\end{tabular}

\section{Source: own survey, 2020}

According to this survey, most of the respondents are illiterate and this has $0.54 \%$ of the respondents are grouped under illiterate, $0.20 \%$ of under writing and reading grouped, the remaining $0.14 \%, 0.10 \%$ and $0.02 \%$ of the respondents are grouped under $1^{\text {st }}-4^{\text {th }}, 5^{\text {th }}-8^{\text {th }}$ and $9^{\text {th }}-10^{\text {th }}$ grade respectively. This information implies that most respondents are illiterate. As these are no education facilities in the area most of respondents in the locality are illiterate whose if found in $46-65$ years old. Because in the early time there was no such expand educational infrastructure in rural area. So this implies that the more illiterate, has an impact on agricultural production (or agricultural development) negatively and low agricultural output because these farmers have no ability to use modern inputs, such as fertilizer, improve seeds, pesticides, improved tools (tractor) and have no to listen current of market and taking of other necessary things.

Table 4: family size of respondents

\begin{tabular}{|l|l|l|}
\hline Family Size & Respondents & Percentages \\
\hline $1-2$ & 4 & 4 \\
\hline $3-4$ & 24 & 24 \\
\hline $5-6$ & 18 & 18 \\
\hline $7-8$ & 54 & 54 \\
\hline Total & 100 & 100 \\
\hline
\end{tabular}

\section{Source; own survey, 2020}

The above table shows $54 \%$ of the respondents have family size of $7-8,18 \%$ of the respondents have family size of $5-6$, and $24 \%$ of $3-4$ and $4 \%$ of the respondents have family size of $1-2$. This implies that the majority of the sample respondents have family size of 7-8. This implies the higher family size leads increasing population in the study area which exerts high pressure in the environment and affect in agricultural output. Because the land size very small and constant but the family size is increasing and the agricultural product become low.

Table 5: Annual income level of respondents

\begin{tabular}{|l|l|l|}
\hline Income & Number of respondents & Percentages \\
\hline $400-1000$ & 42 & 42 \\
\hline $1001-1500$ & 16 & 16 \\
\hline $1501-2000$ & 8 & 8 \\
\hline $2001-2500$ & 24 & 24 \\
\hline Above 2500 & 10 & 10 \\
\hline Total & 100 & 100 \\
\hline
\end{tabular}

\section{Source: own survey, 2020}

The above table shows the majority of respondents earn income between $400-1000$ birr per year from agricultural product which accounts $42 \%, 16 \%$ of the respondents have income earned between $1001-1500,8 \%$ have owned income from 1501 - 2000 birr, $24 \%$ of the respondents earned $2001-2500$ birr per year and the 
remaining $10 \%$ of the respondents have earned above 2500 birr per year from agricultural product. But the majority of the sample respondents have under lower income group. But more factors that affecting the agricultural outputs are shortage of rainfall, small size of land, improperly used of the land. Due to this the agricultural output of the study area is low.

Table 6: land holding of respondent

\begin{tabular}{|l|l|l|l|}
\hline NO & Do you have land? & Number of respondents & Percentages \\
\hline \multirow{4}{*}{1} & YES & 96 & 96 \\
\cline { 2 - 4 } & NO & 4 & 4 \\
\cline { 2 - 4 } & Total & 100 & 100 \\
\hline \multirow{5}{*}{2} & Size land in hectares & - & - \\
\cline { 2 - 4 } & 0.25 & 36 & 37.5 \\
\cline { 2 - 4 } & 0.5 & 28 & 29.5 \\
\cline { 2 - 4 } & 0.75 & 8 & 8.3 \\
\cline { 2 - 4 } & 1 & 8 & 8.3 \\
\cline { 2 - 4 } & Above 1 & 16 & 16.7 \\
\hline & Total & 96 & 100 \\
\hline
\end{tabular}

\section{Source: own survey, 2020}

The above table shows that most of sample respondents have their own land (farm land) which account $96 \%$ and the rest of $4 \%$ have not own lands but the land is not sufficient for the farmers to produce more output. And the second (tab two) shows the size of land.

The majority of the (households) $37.5 \%$ have land size of 0.25 hectare, $29.2 \%$ of household (sample respondents) have Land size of 0.5 hectare, $16.7 \%$ of the sample respondents have Land size above $1,8.3 \%$ of the sample respondents have Land size of 0.75 and 1 hectare. 1and 0.75 -hectare respondents have very small land size. Because of the small and fragmented land, the agriculture product of the society is low.

Table 7: indicates producing method in agricultural production by the sample respondents

\begin{tabular}{|l|l|l|}
\hline Producing method & Number of respondents & Percentages \\
\hline Mechanized & 0 & $0 \%$ \\
\hline Oxen & 70 & $0.70 \%$ \\
\hline Hand dug & 2 & $0.02 \%$ \\
\hline Both hand dug and oxen & 28 & $0.28 \%$ \\
\hline Total & 100 & $1 \%$ \\
\hline
\end{tabular}

\section{Source: own survey, 2020}

The above table indicates $70 \%$ of the produce produced by using (ploughing) only oxen, $28 \%$ of the respondent's plough by using both oxen and hand dug and $2 \%$ of the respondents produced by using hand dug and there are not uses mechanized tools. This implies that the majority of the sample household uses traditional producing method. This in turn leads to low agricultural output because the respondents are not using mechanized farming tools hence unable to produce higher product with less effort time and labor.

Table 8: shows uses of crop rotation by the sample respondents their agricultural activities.

\begin{tabular}{|l|l|l|}
\hline Dou you use crop rotation & Number of respondents & Percentages \\
\hline Yes & 26 & $26 \%$ \\
\hline No & 74 & $74 \%$ \\
\hline Total & 100 & $100 \%$ \\
\hline
\end{tabular}

Source: own survey, 2020

The above table's shows $26 \%$ of the respondents used crop rotation and $74 \%$ of respondent not uses crop rotation. The majority of the sample population not uses crop rotation. Due to lack of awareness, lack of land that cannot suitable for crop rotation and so on. This leads to low agricultural output.

Table 9: shows irrigation activities of the sample respondents

\begin{tabular}{|l|l|l|}
\hline Dou you use irrigation & Number of respondents & Percentages \\
\hline Yes & 14 & $0.14 \%$ \\
\hline No & 86 & $0.86 \%$ \\
\hline Total & 100 & $100 \%$ \\
\hline
\end{tabular}

\section{Source: own survey, 2020}

The majority of $(86 \%)$ of the responded have non user of irrigation and very low $(14 \%)$ of the responded have irrigation user. Irrigation is the most important to increase agriculture output during shortage of rain fall. But most responded have not use irrigation because of lack of awareness, lack of land that cannot suitable for irrigation and so on. Therefore, because of the absence of irrigation the agriculture output is low. 
Table 10: Shows improved seed used and amount of using by sample respondents.

\begin{tabular}{|l|l|l|l|}
\hline No & Do you use improved seed? & Number of respondents & percentages \\
\hline \multirow{3}{*}{1} & Yes & 54 & $54 \%$ \\
\cline { 2 - 4 } & No & 46 & $46 \%$ \\
\cline { 2 - 4 } & Total & 100 & $100 \%$ \\
\hline \multirow{2}{*}{2} & Amount in quintal & - & - \\
\cline { 2 - 4 } & $0.5-1$ & 44 & 81.5 \\
\cline { 2 - 4 } & $2-3$ & 10 & 18.5 \\
\hline & Total & 54 & \\
\hline
\end{tabular}

Source: own survey, 2020

The above table indicated $54 \%$ of the respondents used improved seeds and $46 \%$ of the sample respondents none used improved seeds. But the amount of used in quintal has very low , $81.5 \%$ of the sample respondents used 0.5-1 quintal of improved seed per year, $18.5 \%$ of uses 2-3 quintal of improved seed and. The majority of respondents use very low quintal. due to lack of experience sharing, lack of farmer training and they used local seeds.

Table 11: shows the cultivation period in year by the sample respondent

\begin{tabular}{|l|l|l|}
\hline Cultivation period & Number of respondents & Percentages \\
\hline Once a year & 86 & $86 \%$ \\
\hline Twice a year & 14 & $14 \%$ \\
\hline Three times a year & 0 & 0 \\
\hline Total & 100 & $100 \%$ \\
\hline
\end{tabular}

Source: own survey 2020

In the study area, agricultural production is seasonable which mean that they depend on rain fall. As indicated in the above table $86 \%$ of the sample respondents cultivated once a year and $14 \%$ of the sample respondents cultivated twice in some times a year. From the total number of respondents $86 \%$ of the respondents that as they are Influenced by shortage of water irrigation in order to produce agricultural output twice year and inadequate them to produce once a year. Because of the factors and other the agricultural output is very low and leading to seeking to government aid like safety net program.

\subsection{The main factors affecting low agricultural output}

Agricultural is the process of development, increasing food supply and rural income to enlarge market for urban output as well as provide resources to expand output. However, agricultural productivity is low and there by low output because of traditional way of farming. Agricultural output in the developing countries is decrease due to different factors like, climate change, the degradation of land, low soil fertility, illiteracy, lack of quality seeds, lack of entrepreneurship in agricultural zone, weak at agricultural structure internal and international migration and draught, most farmers in developing countries are characterized by dependency of traditional instrument and farming practice. In addition to this, proper production practice is not utilized and farmers systems are traditional and backward, land preparation, planting methods, seeding rate, crop production cultivation and harvesting are not performed properly. According to the surveyed sample there are many factors that affect low agricultural output in the study area and analyzed in the following table.

Table 12 shows main factors affecting low agricultural output on the sample respondents

\begin{tabular}{|c|c|c|}
\hline Factors & $\begin{array}{l}\text { Numbers } \\
\text { respondents }\end{array}$ & Percentages \\
\hline Rain fall traditional method, land fragmentation & 40 & $0.40 \%$ \\
\hline $\begin{array}{l}\text { Lack of technological inputs like, fertilizer, improved seed pesticides, } \\
\text { herbicides }\end{array}$ & 28 & $0.28 \%$ \\
\hline Soil erosion, deforestation & 8 & $0.08 \%$ \\
\hline Lack of extension service like, experience sharing. & 8 & $0.08 \%$ \\
\hline $\begin{array}{l}\text { Lack of oxen of awareness, natural hazards, low fertility of land, high } \\
\text { price of fertilizer }\end{array}$ & 16 & $0.16 \%$ \\
\hline Total & 100 & $1 \%$ \\
\hline
\end{tabular}

Source: own survey 2020

As we can see in the above table most respondents $40 \%$ of the sample respondents respond there is high variation of rainfall, land fragmentation or small land producing by traditional method in the areas. If there is high variation of rainfall, there will be risk and uncertainty on the rural people when they start their activities (or to plough) because are depend on rain fall so as to produce their agricultural products. And as the respondents said there is shortage of land (land fragmentation), And $28 \%$ of the sample respondents have problem on lack of technologies inputs like, fertilizer, improved seed, pesticides, herbicides, $8 \%$ of the sample respondents affected 
their lands by soil erosion and deforestation are the main problems of agricultural output, this increase from time to time due to higher population. $8 \%$ of the sample respondents have problem on lack of extension service. $16 \%$ of the sample respondent have problem on lack of oxen, lack of awareness, natural hazards, low fertility of land and high price of fertilizer. By this and other factors the agriculture output of the household is low.

Table 13: the adverse effect determinants of agricultural output

\begin{tabular}{|l|l|l|}
\hline The adverse effect & Number of respondents & Percentages \\
\hline Low yield of output & 78 & $78 \%$ \\
\hline Shortage of food & 22 & $22 \%$ \\
\hline Total & 100 & $100 \%$ \\
\hline
\end{tabular}

Source: own survey 2020

From the above table $78 \%$ of the sample respondent experienced a low yield of output, $22 \%$ of the sample respondent is shortage (insufficient) of food. It implies that the adverse effect determinants of agricultural output lead to lack of self - confidence, poor management system to their survival, Migration and depend on governmental aid and non government aid like safety net and miss management on their survival.

\section{Conclusion and recommendation}

The major finding of the study from the questionnaire indicated that the existence of low agricultural output in the study area, which directly influences growth of its output and land productiveness is below what it should be so as to fulfill the minimum food requirements of the area. Female participation in agricultural activities is very low and leads to low agricultural output. Most of farmers in Doba woreda are illiterate and have no awareness about modern farming system and their level of income is also low. In Doba woreda the farmers owned and cultivated a land of very small size. Most households in the woreda have less access to micro finance institutions credit system, extension service, farmer training, and sharing experience and did not use more modern inputs like fertilizers, improved seeds, herbicides, pesticides, tools of agricultural. This leads to low agricultural outputs. Most households in the woreda have less fertile land.

This leads to low agricultural outputs. Most farmers have not enough Oxen and most of the societies use traditional production method, and traditional fertilizers, majority of the farmers practiced ploughing by oxen, both oxen and dug and agricultural output become low. Most farmers in the woreda used very low improved seed, irrigation, crop rotation and modern fertilizer. The distance from home to the farm \& from home to the market is very far for most farmers. This affects the farmer productivity. Cultivation period of production in the Woreda is once a year and because of rainfall variability; soil erosion and desertification are expanding agricultural lands and increasing of the number of populations from time to time.

The farmer should enhance the land quality through improve soil structure, organic matter and controlling land degrading, cropping and pasturing practice contribution to production intensification and sustainable land use. Women's affairs office, educated people, and other concerned body should work in order to change the backward social attitudes that undermine women and increases the productive capacity of women in agricultural production and the government should create awareness for female and avoid bad culture influencing towards agriculture. Government and other concerned body should go through the provision of agricultural extension, motivation and promoting the expansion of credit institution in the rural area advisory service on continuous basis in addition proving advanced technologies. Modern agricultural inputs are beyond the capacity of farmer to purchase because of their expensiveness. So, government should distribute these inputs with low price by subsidizing and providing access to credit with low interest rate to bring desired economic development.

The demand of modern fertilizers is very low in the woreda because of high price. So, the government should distribute at low price and to increase the demand of these inputs. To increase agricultural output the government should provide the infrastructure, and to make the market nearest to the society. To increase agricultural output the government should provide the extension service to the farmers and agricultural office managers should give training to small scale farmers, giving advice and awareness for the illiterate farmers about importance of modern technology, improved seeds and other mechanisms of that improving the agricultural output. The farmers should use different mechanisms to control the factors affecting agricultural output like using irrigation for uncertainty of rainfall distribution, by reforestation for conservation of forests, using crop rotation and other mechanisms should be taken carefully.

\section{Reference}

[1]. Ayele Kuris (2016), the Ethiopian economic principle and practice second edition, Ethiopia commercial printing press Addis Ababa.

[2]. Todaro (2014), Economic development $7^{\text {th }}$ edition.

[3]. Befkadu Degefe (2015) annual report on Ethiopia economy A.A Ethiopia VO/I .

[4]. Berhanu Nega (2016), Annual report on Ethiopia economy A.A Ethiopia Vo/I by united printer

[5]. CSA (2015) central statistical Agency 
[6]. Degne Aredo (2014) Agricultural Economic draft teaching material

[7]. Mulat Demeke, the structure and performable Ethiopia Agriculture Ethiopia Addis Ababa. November 2017

[8]. Todaro (2016) Economic development $8^{\text {th }}$ edition

[9]. EEA, Ethiopia Association 2012 Annual Report on Ethiop Economy VO/I Addis Ababa Ethiopia Economic Association.

[10].Befekadu Degefe and BerhanuNega (2014) Annual Report on the Ethiopia Economy, the Ethiopia Economic Association VO/I, 2014 Addis Ababa

[11]. Workneh Ngatu (2018) land tenure and technological improvements in smallholder agriculture in Ethiopia and challenge of sustainable development.

[12].FDRE, 2016, food security strategy, prepared for the consultative Group meeting of December 10-12 Addis Ababa Ethiopia. Mulat Demeke (2014), challenges of increasing food production in Ethiopia. FAO, (2015) special report on crop and food supply.

[13]. Judicial Dictionary (2001), Definition of Agriculture $3^{\text {rd }}$ education in New Delhi.

[14].WFPL/FAO (2009), special report on Ethiopia Economy. 